\title{
Evolución histórico-filosófica del pensamiento científico. Su aporte a la enseñanza de las ciencias experimentales
}

\author{
Fabro, Ana Patricia
}

\section{Resumen}

La metodología basada en la corroboración de conceptos científicos, utilizada para la enseñanza de las ciencias experimentales, es importante para la formación inicial del estudiante en las disciplinas. Sin embargo, no logra transmitir al estudiante la historicidad de los descubrimientos científicos, ni la comprensión de los problemas conceptuales para el desarrollo de nuevos dominios de la investigación científica, o para el avance de los ya vigentes.

Quienes tenemos la responsabilidad de formar a los alumnos en los diversos campos de la ciencia, tenemos el deber de enseñarles los conceptos disciplinares específicos, pero también brindarles los elementos que los capaciten para enfrentar nuevos desafíos en investigación.

Para ello, es fundamental que los alumnos conozcan el proceso de elaboración del conocimiento científico, con sus dudas e incertidumbres. Al mismo tiempo es necesario que comprendan cómo la legitimación y aceptación de las grandes teorías estuvieron bajo la influencia de factores políticos, económicos y sociales.

En este sentido, la finalidad del presente trabajo es reflexionar sobre la enseñanza de las ciencias experimentales, desde una visión mucho más holística. Se busca contribuir a resaltar la importancia de la dimensión histórica y filosófica de la ciencia, como medio para promover discusiones sobre los mecanismos de construcción del conocimiento científico.

Palabras clave: reflexión, enseñanza, ciencias experimentales.

Presentado: 19-9-12 | Aceptado: 2-11-12

Profesora Adjunta de la Cátedra de Morfología Normal.

Facultad de Bioquímica y Ciencias Biológicas. UNL.

Ciudad Universitaria. Paraje El Pozo.

Santa Fe. Provincia de Santa Fe. Argentina.

Teléfono: 4525709. Interno 150.

E mail: dantepanozzo@hotmail.com 


\section{Sumary}

\section{Offering evolution of scientific thinking.}

\section{His contribution to the teaching of the experimental sciences}

The methodology based on corroboration of scientific concepts, used for experimental science education, it is important for the initial training of students in the disciplines. However, the student fails to convey the historicity of scientific discovery, and understanding of the conceptual problems for developing new domains of scientific research, or for the advancement of those already existing.

Those who have the responsibility to train students in various fields of science, we have a duty to teach specific nursing concepts, but also provide the elements that enable them to meet new challenges in research.

It is therefore essential that students know the process of scientific knowledge, with their doubts and uncertainties. At the same time it is necessary to understand how the legitimacy and acceptance of the great theories were under the influence of political, economic and social factors.

In this sense, the purpose of this paper is to reflect on the teaching of experimental sciences, from a much more holistic vision. It seeks to contribute to highlight the importance of the historical and philosophical dimension of science, as a means to promote discussion of the mechanisms of construction of scientific knowledge.

Keywords: reflection, teaching-experimental sciences. 